OPEN ACCESS

Edited by:

Matthew D. Johnson,

Woods Hole Oceanographic Institution, United States

Reviewed by: Jelena Godrijan,

Bigelow Laboratory for Ocean Sciences, United States Kemal Can Bizsel, Dokuz Eylül University, Turkey

*Correspondence: Helga do Rosario Gomes helga@/deo.columbia.edu

Specialty section: This article was submitted to Marine Ecosystem Ecology, a section of the journal Frontiers in Marine Science

Received: 28 June 2018 Accepted: 26 September 2018 Published: 23 October 2018

Citation: Gomes HdR, McKee K, Mile A, Thandapu S, Al-Hashmi K, Jiang $X$ and Goes Jl (2018) Influence of Light Availability and Prey Type on the Growth and Photo-Physiological Rates of the Mixotroph Noctiluca scintillans. Front. Mar. Sci. 5:374. doi: 10.3389/fmars.2018.00374

\section{Influence of Light Availability and Prey Type on the Growth and Photo-Physiological Rates of the Mixotroph Noctiluca scintillans}

\author{
Helga do Rosario Gomes ${ }^{*}$, Kali McKee', Anxhela Mile², Sharanya Thandapu ${ }^{3}$, \\ Khalid Al-Hashmi ${ }^{4}$, Xiaojian Jiang ${ }^{1,5}$ and Joaquim I. Goes ${ }^{1}$
}

1 Lamont-Doherty Earth Observatory at Columbia, Palisades, NY, United States, ${ }^{2}$ Elisabeth Haub School of Law at Pace University, White Plains, NY, United States, ${ }^{3}$ Washington University in St. Louis, St. Louis, MO, United States, ${ }^{4}$ Department of Marine Science and Fisheries Sultanate of Oman, Sultan Qaboos University, Muscat, Oman, ${ }^{5}$ School of Life Sciences, Huaiyin Normal University, Huai'an, China

A strain of the mixotrophic green Noctiluca scintillans (Noctiluca) isolated from the Arabian Sea afforded us an opportunity to investigate the photosynthetic and feeding characteristics of this organism which has recently replaced the once diatom dominated food chain of winter blooms in the Arabian Sea. Here we present the first in a series of experiments undertaken to study the interactive effects of irradiance and grazing response of this mixotroph to four phytoplankton species provided as food. Noctiluca showed a distinct preference for the dinoflagellate Peridinium foliaceum and the pennate diatom Phaeodactylum tricornutum, but not for the chlorophyte Pyramimonas sp., nor the chain forming diatom Thalassiosira weissflogii. However, irrespective of the food provided, adequate light was required for Noctiluca to grow as evidenced by its maximum growth rates of 0.3 day $^{-1}$ when fed the preferred dinoflagellate Peridinium and exposed to optimal irradiance of $250 \mu \mathrm{E} \mathrm{m}^{-2} \mathrm{~s}^{-1}$ vs. growth rates of 0.13 day $^{-1}$ with the same food but at a low irradiance of $10 \mu \mathrm{E} \mathrm{m}^{-2} \mathrm{~s}^{-1}$. Measurements of Noctiluca's electron transport rates (ETR) per PSII Reaction Center as a function of irradiance also indicated severe light limitation of photosynthesis at $10 \mu \mathrm{E} \mathrm{m}^{-2} \mathrm{~s}^{-1}$. The active fluorescence derived ETR vs. Irradiance curves also revealed an interesting finding in that there was no significant difference in photosynthetic parameters such as the maximum photosynthetic capacity $\left(E T R_{\max }\right)$ nor $\alpha$, the rate of increase of photosynthesis with light between fed and unfed cells under optimal light conditions. These results suggest that feeding does not enhance the photosynthetic activity of the endosymbionts when nutrients are not limiting as was the case in these experiments. Measurements of Noctiluca's intracellular ammonium concentrations under optimal light conditions, the first for this strain, show significant accumulation of $\mathrm{NH}_{4}{ }^{+}\left(0.003-0.012 \mu \mathrm{M} \mathrm{NH}_{4}{ }^{+}\right.$cell $\left.{ }^{-1}\right)$ after 14 days for fed and unfed Noctiluca which was undetectable 4 days later. A similar 14-day increase but of significantly higher 
concentrations $\left(0.005-0.08 \mu \mathrm{M} \mathrm{NH}_{4}{ }^{+}\right.$cell $\left.^{-1}\right)$ was obtained under low light conditions. For $P$. tricornutum and T. weissflogii fed cultures under light limitation, $\mathrm{NH}_{4}{ }^{+}$continued to increase past the 14-day period suggesting a strong and efficient mechanism for regulation of intracellular nutrients by Noctiluca.

Keywords: mixotroph, blooms, Arabian Sea, feeding, green Noctiluca scintillans, photosynthesis

\section{INTRODUCTION}

Several informative reviews (Stoecker et al., 2009, 2017; Caron, 2016; Mitra et al., 2016; Leles et al., 2017) now urge researchers to recognize that autotrophy (obtaining energy for growth from light) and heterotrophy (utilizing preformed organic matter produced by autotrophs to meet their energy and carbon needs) may often not be mutually exclusive behaviors and many plankton do in fact exhibit some combination of these nutritional modes, an ability generally referred to as mixotrophy (Caron, 2017). Mixotrophy is not confined to just a few unique taxonomic groups but, rather is ubiquitous and occurs amongst different species and in diverse habitats from marine coastal to open ocean systems as well as in freshwater systems (Mitra et al., 2014).

Recognizing that the majority of protists are mixotrophs and engaged in varying proportions of phototrophy and phagotrophy, Mitra et al. (2016) and Stoecker et al. (2017) grouped them into one of three general behavioral categories. Firstly, phagotrophic phytoflagellates that possess chloroplasts but also engulf and digest small prey by phagocytosis, secondly, kleptoplastidic protists, heterotrophic species that feed on algae, partially digest them, but retain their chloroplasts in a functional state (Caron, 2017). The third and perhaps least studied of categories are protists or zooplankton with algal endosymbionts of only one species or very closely related algal species (Stoecker et al., 2017). The best example of such mixotrophy is the dinoflagellate Noctiluca scintillans (herein referred to as Noctiluca as there is only one species in the genus Noctiluca) which harbors thousands of free-swimming endosymbiotic green algae. In contrast, to the exclusively heterotrophic red Noctiluca which is globally ubiquitous, green Noctiluca, is much more restricted and limited mainly to tropical southeast Asian waters and parts of the Arabian Sea, Gulf of Oman, and the Red Sea (Harrison et al., 2011). Localized blooms of this green endosymbiont carrying Noctiluca have been recurring in Southeast Asian waters such as in the Manila Bay, the upper Gulf of Thailand, and Jakarta Bay (Furuya et al., 2006a,b), in the coastal waters of Vietnam and Cambodia (Harrison et al., 2011) and further west in the Sea of Oman (also known as the Gulf of Oman) (Al-Azri et al., 2012; Al-Hashmi et al., 2015). In the early 2000s, using microscopy in conjunction with ocean color imagery we reported (Gomes et al., 2008, 2009) for the first time, large scale and recurrent blooms of the green Noctiluca in the northern Arabian Sea. The Noctiluca of the Arabian Sea is large (diameter of $\sim 600-1000 \mu \mathrm{m}$ ), bulbous and harbors thousands of endosymbionts, which swim freely within its large central vacuole (Figure 1). On the basis of molecular analysis and the priority rule of nomenclature, the ecological characteristics of the endosymbionts within Noctiluca have been reclassified as Protoeuglena noctilucae (Wang et al., 2016) instead of Pedinomonas noctilucae, the earlier species name given in Sweeney (1976).

Thick surface blooms of Noctiluca are now becoming more pervasive and widespread throughout the northern and central AS, causing a radical shift in the usually diatom dominant winter monsoonal blooms, one of the two high productivity periods in the otherwise oligotrophic Arabian Sea (Gomes et al., 2008; Goes et al., 2018). In Gomes et al. (2014) we showed that a combination of its ability to feed on extraneous phytoplankton prey and the recent spread of hypoxia in the Arabian Sea were favoring the growth of Noctiluca over that of diatoms.

Specifically, we observed that Noctiluca have higher rates of carbon fixation in hypoxic waters as compared to diatoms (Gomes et al., 2014). $\mathrm{O}_{2}$ deficiency $(<4 \mu \mathrm{M})$ and a permanent oxygen minimum zone (OMZ) at mid-depths $(>120 \mathrm{~m})$ is a unique feature of the northeastern Arabian Sea, a consequence of high surface productivity of the semi-annual phytoplankton blooms (Goes et al., 2005), sub-thermocline source waters that have naturally low dissolved $\mathrm{O}_{2}$ content flowing from the Southern Ocean and poor ventilation of subsurface waters in the landlocked north (Morrison et al., 1999). Comparison of $\mathrm{O}_{2}$ saturation data from our recent studies with historic data (Gomes et al., 2014) showed that the Arabian Sea's euphotic zone was indeed experiencing an influx of hypoxic waters from an expanding OMZ. A recent study by Lachkar et al. (2017) confirmed the findings of Gomes et al. (2014). This phenomenon is not confined only to the Arabian Sea but is being experienced in many regions of the world (Breitburg et al., 2018) because of human activities that have increased global temperatures and nutrients discharged to coastal waters. Coupled with this unique functional and adaptive response of Noctiluca and its endosymbiont to hypoxia, is its voracious predation of diatoms and other phytoplankton that form the winter blooms of the Arabian Sea fueled by new nitrogen inputs from convective mixing (Banse and McClain, 1986).

Noctiluca's requirement for inorganic nutrients for photosynthesis by its endosymbionts, and its ability to graze on other phytoplankton suggests that it competes for resources (nutrients and prey) with both its prey and predators but little is known about how it regulates its photosynthetic and heterotrophic processes. The few studies, reviewed in Harrison et al. (2011) suggest that although Noctiluca can grow photo-autotrophically for several generations, phagotrophy promotes faster growth and is a requirement for bloom formation (Sriwoon et al., 2008). Feeding experiments conducted during a bloom in the Arabian Sea to elucidate the 


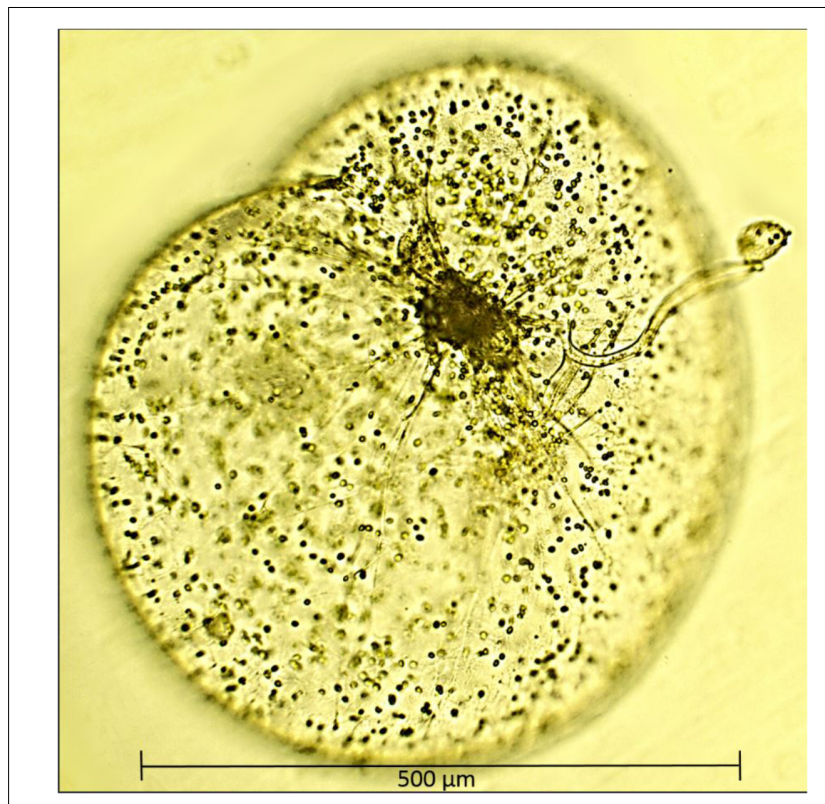

FIGURE 1 | A single cell of Noctiluca scintillans with free-swimming endosymbionts Protoeuglena noctilucae using its tentacle to capture algal cells for feeding. Image was produced with a epifluorescence microscope (OMAX 40X-2500X) with a 40x objective. interplay between dependence of Noctiluca on its autotrophic endosymbionts and its facultative phagotrophy (Gomes et al., 2014) showed that growth rates of Noctiluca were much lower in the dark even with addition of food as compared to rates for cells grown in the light indicating the importance of autotrophic endosymbionts for growth. Even more interesting was the fact that growth rates in samples where light and nutrients were provided were comparable to those where light and food (but not nutrients) were provided. Growth rates did not increase when nutrients were added to flasks containing food and exposed to light, suggesting that when food is available, Noctiluca is capable of meeting a large fraction of its metabolic requirements via phagotrophy. What was lacking in this study was knowledge of whether Noctiluca had food preferences although the general consensus based on experimental evidence with red Noctiluca is that it is not particularly selective (Elbrachter and Qi, 1998; Zhang et al., 2016).

On account of the paucity of information on this unique and novel organism, little is known on the regulation and interplay between photosynthetic and heterotrophic processes, key information required to understand its recent proliferation in tropical waters (Furuya et al., 2006a,b; Harrison et al., 2011; Al-Azri et al., 2012; Al-Hashmi et al., 2015). An isolate from the Arabian Sea afforded us with an opportunity to conduct controlled, laboratory experiments. This culture is more akin to that of Furuya et al. (2006b) and Saito et al. (2006) from the Manila Bay because it grows in a $12 \mathrm{~h}$ light-dark cycle, without food for more than a year and even without the addition of fresh media. It differs from the one described by Sweeney (1971) and
Hansen et al. (2004) which could survive and divide in the light with or without addition of food for only about a month.

In this series of experiments described in detail below, we fed the laboratory grown strain of Noctiluca with four phytoplankton species viz. Two diatoms, Phaeodactylum tricornutum and Thalassiosira weissflogii, a dinoflagellate Peridinium foliaceum and a green alga Pyramimonas sp. In addition to counting Noctiluca cells to ascertain growth with the different foods provided, we also assessed the photosynthetic efficiency of the green endosymbionts using photosynthesis-irradiance responses (Platt and Jassby, 1976).

Additionally, we conducted preliminary measurements on the $\mathrm{NH}_{4}{ }^{+}$content of Noctiluca cells. This aspect of Noctiluca has rarely been addressed although it is known that the heterotrophic red variety of Noctiluca accumulates large quantities of $\mathrm{NH}_{4}{ }^{+}$ (Okaichi and Nishio, 1976) which makes it buoyant (Furuya et al., 2006a). This is also the case with Noctiluca blooms in the Arabian Sea which form green carpets over large expanses of the sea even though this exposes them to inhibitory light levels (Goes and Gomes, 2016).

\section{MATERIALS AND METHODS}

\section{Prey and Predator Cultures}

Noctiluca cells isolated from the open waters of the Arabian Sea are maintained in $f / 20$ medium without silicate $(f / 20-\mathrm{Si})$ in polycarbonate bottles at $26^{\circ} \mathrm{C}$ and exposed to a light intensity of approximately $200 \mu \mathrm{E} \mathrm{m}^{-2} \mathrm{~s}^{-1}$ and a photoperiod of $11.5 \mathrm{~h}$ light: $12.5 \mathrm{~h}$ dark. This culture is maintained without extraneous food.

The four prey cultures used in the feeding experiments were isolated from warm tropical waters and include a pennate diatom (P. tricornutum; CCMP632, cell dimensions of 18-26 $\mu \mathrm{m}$ ), a centric diatom ( $T$. weissflogii; CCMP1336, cell dimensions of $12-22 \mu \mathrm{m}$ ), and one chlorophyte (Pyramimonas c.f. sp.; CCMP1239, cell dimensions of 5-10 $\mu \mathrm{m}$ ) all obtained from the NCMA, Bigelow Laboratory for Ocean Sciences, ME, United States). A fourth, the dinoflagellate $P$. foliaceum (cell dimensions of 5-10 $\mu \mathrm{m}$ ) was obtained from Dr. E. J. Buskey, University of Texas, TX, United States. P. tricornutum and T. weissflogii are grown in $\mathrm{f} / 2$ medium; while Pyramimonas and $P$. foliaceum are grown in $\mathrm{f} / 2-\mathrm{Si}$. All prey cultures are maintained at $26^{\circ} \mathrm{C}$ with a light intensity of approximately $200 \mu \mathrm{E} \mathrm{m}^{-2} \mathrm{~s}^{-1}$ and a photoperiod of $11 \mathrm{~h}$ Light: $13 \mathrm{~h}$ Dark. Growth media for the prey cultures was prepared in $0.22 \mu \mathrm{m}$ membrane filtered seawater (FSW) according to protocols provided by NCMA. Growth and grazing experiments were started once all cultures had reached exponential phase.

\section{Experimental Setup}

All polycarbonate bottles in which the experiments were conducted were acid-washed and soaked overnight with 5\% technical grade $\mathrm{HCl}$, rinsed with Milli-Q distilled water, and autoclaved prior to use. A schematic of the experimental setup is shown in Supplementary Figure S1.

Twenty cleaned $250 \mathrm{~mL}$ polycarbonate bottles were filled with $200 \mathrm{~mL}$ of sterile f/20 - Si medium and 50 Noctiluca cells 
were added to each of them. Cells were picked individually using plastic transfer pipettes, and washed in sterile FSW before being introduced into the bottles. Ten of these bottles containing Noctiluca were placed in light replete (HL, $250 \mu \mathrm{E} \mathrm{m} \mathrm{m}^{-2} \mathrm{~s}^{-1}$ ) conditions and 10 in light limited (LL, $10 \mu \mathrm{E} \mathrm{m}^{-2} \mathrm{~s}^{-1}$ ) conditions in an incubator at $26^{\circ} \mathrm{C}$. LL conditions were simulated by covering the cool white light fluorescent tubes of the lower tiers of the incubator with neutral density filters. Aliquots of each of the four prey suspensions were added to eight bottles reserved for the HL treatment so that each prey treatment had two duplicate bottles. The volume of prey approximated 1-2 $\mu \mathrm{g}$ $\mathrm{L}^{-1}$ Chlorophyll $a$ (Chl $a$, a proxy for biomass) per bottle (volume of culture was $3.29 \mathrm{~mL}$ for Pyramimonas sp. and $<1 \mathrm{~mL}$ for the other three prey cultures). No food was added to the remaining two Noctiluca bottles which served as controls. The setup for the 10 LL bottles was identical to the one described for the 10 HL bottles. Four additional bottles with only prey cultures were placed in the HL section of the incubator. Based on preliminary work, Noctiluca was allowed to adapt to the four prey cultures for 7 days. All bottles were maintained at $26^{\circ} \mathrm{C}$ with a photoperiod of $11.5 \mathrm{~h}$ light: $12.5 \mathrm{~h}$ dark for 27 days on three dimensional gyratory rockers to gently agitate the cells and encourage natural interaction between predator and prey.

Details of the sampling protocols and of all measurements conducted are presented below.

\section{Sampling and Measurements}

Measurements were made to assess the growth and feeding rates of Noctiluca and the photo-physiology of the cells as follows:

\section{Chl a}

Chl $a$, was measured fluorometrically (Holm-Hansen and Riemann, 1978) using a Turner ${ }^{\circledR}$ Designs Trilogy Laboratory Fluorometer to determine the initial biomass of the four stock prey cultures prior to being fed to Noctiluca. Chl $a$ was extracted in acetone in cells filtered through $0.7 \mu \mathrm{m}$ Whatman ${ }^{\circledR} \mathrm{GF} / \mathrm{F}$ glass filters. The same procedure was employed to measure $\mathrm{Chl}$ $a$ during the course of the experiment.

\section{Cell Counts}

Cell counts of prey prior to being fed and during the course of the experiment were undertaken using FlowCAM ${ }^{\circledR}$, an imaging particle analyzer that combines imaging and laser light to detect particles and capture their images which are then identified from pre-built libraries (Poulton, 2016). Prey counts were made by drawing $4.9 \mathrm{~mL}$ of culture in duplicate from each of the bottles, which was preserved with $0.1 \mathrm{~mL}$ neutral Lugol's iodine solution. Care was taken to draw this sub-sample from the bottom, and if any Noctiluca cells were observed in the transfer pipette the process was repeated until we are assured that the sub-sample had no Noctiluca cells.

To obtain Noctiluca counts, $5 \mathrm{ml}$ of media from each bottle was drawn into a sterile plastic transfer pipette and the number of individual cells in the pipette was counted before the volume was returned to the bottle. This process was repeated five times to ascertain accuracy. Noctiluca's large size allowed us to count cells using this non-invasive method.

\section{Photophysiology Using Fluorescence Inductance and Relaxation (FIRe)}

A suite of photosynthetic and physiological characteristics of Noctiluca's endosymbionts was assessed using the Fluorescence Inductance and relaxation technique in a mini-FIRe benchtop instrument (Gorbunov and Falkowski, 2004; Park et al., 2013).

Variable Fluorescence, a unique property of the photosynthetic machinery (Gorbunov and Falkowski, 2004) is related to the efficiency of photosynthetic processes and provides us with estimates of the physiological status of photosynthetic organisms (Kolber et al., 1998). Variable Fluorescence $\left(\mathrm{F}_{\mathrm{V}}\right)$ is calculated using initial $\left(\mathrm{F}_{0}\right)$ and maximum $\left(F_{M}\right)$ fluorescence after illumination with a high-energy flash $\left(\mathrm{F}_{\mathrm{V}}=\mathrm{F}_{\mathrm{M}}-\mathrm{F}_{0}\right)$. Quantum efficiency of the photochemistry in Photosystem II (PSII), a relative measure of the electron transport efficiency is the ratio of the Variable Florescence $\mathrm{Fv}_{\mathrm{V}}$ and the maximum Fluorescence Fm, i.e., $\mathrm{F}_{\mathrm{V}} / \mathrm{F}_{\mathrm{M}}$. High $\mathrm{F}_{\mathrm{V}} / \mathrm{F}_{\mathrm{M}}$ is associated with a functioning PSII and, therefore, is a proximal measurement of cellular integrity and metabolic capability while fluctuations may indicate "stressful growth" such as nutrient starvation or excessive light (Suggett et al., 2009). Variable Fluorescence can then be used to calculate parameters that characterize photosynthetic light-harvesting processes, the photochemistry in PSII, and the photosynthetic electron transport down to carbon fixation. In addition to the quantum efficiency of PSII $\left(\mathrm{F}_{\mathrm{V}} / \mathrm{F}_{\mathrm{M}}\right)$ our FIRe system also provides the cross section of PSII ( $\sigma$ PSII), which is a measure of the size of the light-harvesting antenna system associated with PSII (Bibby et al., 2008).

Using these parameters we can then calculate the photosynthetic ETR per PSII Reaction Center (RC) as described in Park et al. (2013) which is related to the rate of primary production or carbon fixation (Gorbunov and Falkowski, 2004). Using FIRe, ETR measurements were performed over a range of light levels using an Actinic Light Source to obtain ETR rates as a function of irradiance. These ETR-Irradiance curves (ETR-E) are similar to the Photosynthesis-Irradiance curves (P-E) (Platt and Sathyendranath, 1988) that have been used widely to measure primary productivity at basin or global scales (Platt et al., 1980; Bouman et al., 2005) and serve to understand the acclimation state of the phytoplankton and as indicators of the influences of environmental factors such as light and nutrients on primary production (Falkowski et al., 1981; Henley, 1993). These ETR-E curves like the Photosynthesis-Irradiance curves provide parameters such as maximum ETR (ETRmax), $\alpha$, the initial light-limited slope and saturation irradiance $\mathrm{E}_{\mathrm{k}}$ (Platt et al., 1980; Park et al., 2013; Houliez et al., 2017). Depending on the presence or absence of photoinhibition two different models of (Platt et al., 1980) were fitted to the ETR data. All curve fitting was done using MATLAB 2016b routines.

In order to conduct the above measurements, 10 Noctiluca cells from each bottle were carefully picked with transfer pipettes, 
cleaned in sterile FSW to prevent the carryover of prey and suspended into glass tubes containing sterile FSW. The glass cuvette was inserted into the compartment and the actinic light source (ALS) was placed on top of the holder. The length of the multi-turnover flash (MTF) was set to $100 \mathrm{~ms}$, the number of pulses in the relaxation sequence (MTRP) was set to 40, while the maximum PAR for the ALS was set to $1200 \mu \mathrm{mole} / \mathrm{m}^{2} / \mathrm{s}$. The number of PAR steps was set to 10 , and the time delay in which the ALS was on prior to data acquisition was set to $5 \mathrm{~s}$. To acquire the parameters described above the data was further processed with a program supplied with the instrument.

Known aliquots of $\mathrm{f} / 20$ - Si medium were added to the sample bottles to account for any loss in volume occurring after sampling. After the FIRe measurements, the same samples containing the 10 Noctiluca cells were used to measure Chl $a$ of the endosymbionts using the fluorometric method described above. FIRe measurements were also conducted with prey samples without Noctiluca to estimate the photophysiological status of the prey. We could not conduct weekly FIRe or Chl $a$ estimates of the prey in the bottles because we have observed in our routine maintenance of Noctiluca that it ejects out its endosymbionts. So we instead relied on FlowCAM ${ }^{\circledR}$ derived cell counts of prey samples which were more accurate.

\section{Intracellular Ammonium Concentrations}

$\mathrm{NH}_{4}{ }^{+}$accumulation in Noctiluca cells was measured at the start of the experiment, and after 14 and 18 days. This was done by placing five washed and cleaned cells into $15 \mathrm{~mL}$ plastic centrifuge tubes containing $10 \mathrm{~mL}$ Milli-Q distilled water. The process was repeated with five more cells to obtain replicates. Samples were collected in duplicate, vortexed, and frozen at $-80^{\circ} \mathrm{C}$ prior to analysis. Ammonium was measured colorimetrically with the Turner Designs Trilogy laboratory fluorometer according to Holmes et al. (1999).

\section{Growth Rate Calculations}

Growth Rates $(\mu)$ of Noctiluca, measured as the change in cell number over time, were computed using the formula:

$$
\mu=\left[\ln \left(N t_{1} / N t_{0}\right)\right] t^{-1}
$$

where $N t_{0}=$ concentration of cells at time 0 (cells $\mathrm{ml}^{-1}$ ), $N t_{1}=$ concentration of cells at time 1 (cells $\left.\mathrm{ml}^{-1}\right)$, and $t=$ duration of each experiment $(\mathrm{d})$.

\section{Statistics}

All statistical tests used to test the significance of differences in growth of Noctiluca as well as differences in photosynthetic

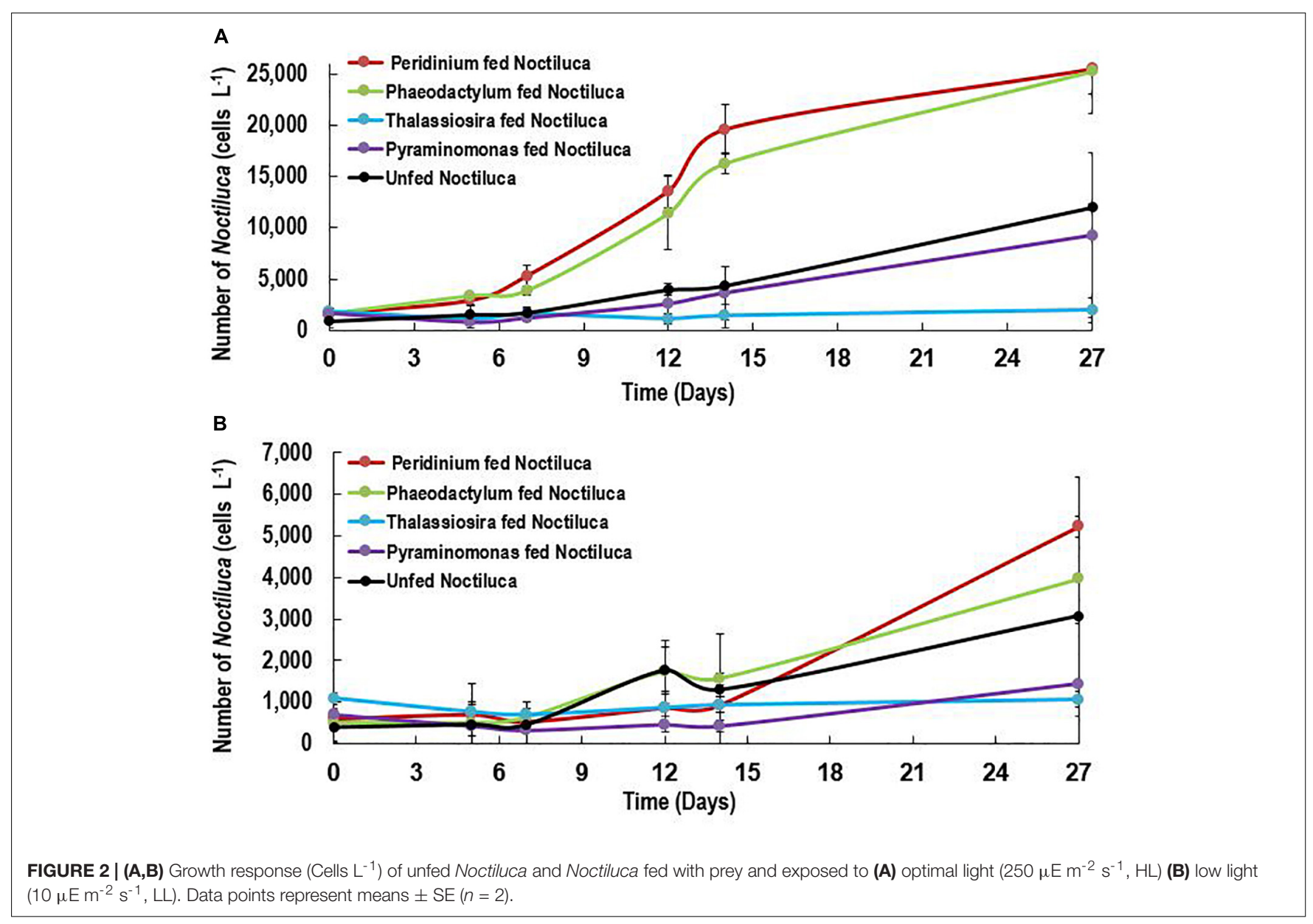




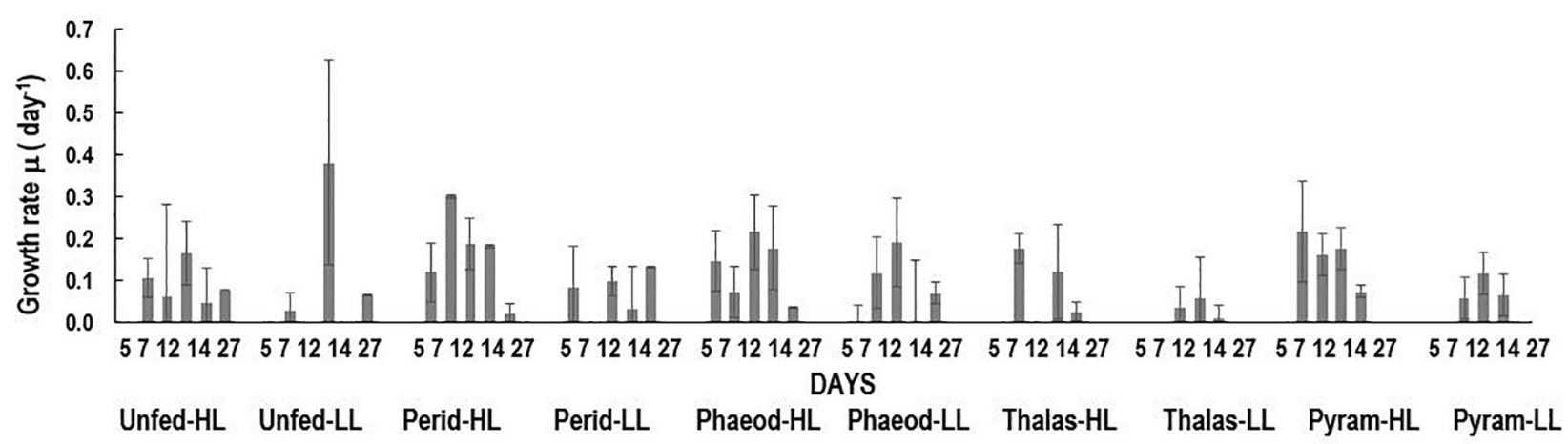

FIGURE 3 | Growth rates (day ${ }^{-1}$ ) over the course of the experiment for unfed Noctiluca and for Noctiluca fed P. foliaceum (Perid), P. tricornutum (Phaeod), T. weissflogii (Thalas), and Pyramimonas sp. (Pyram) and exposed to optimal (250 $\left.\mu \mathrm{E} \mathrm{m}^{-2} \mathrm{~s}^{-1}, \mathrm{HL}\right)$ and low light (10 $\mu \mathrm{E} \mathrm{m}^{-2} \mathrm{~s}^{-1}$, LL). Data points represent means $\pm \operatorname{SE}(n=2)\left(\right.$ day $\left.^{-1}\right)$.

parameters of the ETR-E curves were performed using JMP $9^{\circledR}$ software.

\section{RESULTS}

\section{Growth of Noctiluca With and Without Food}

Of the four phytoplankton species provided as food and exposed to HL and LL conditions, the green Noctiluca culture currently growing in our laboratory, showed a distinct preference for the diatom $P$. tricornutum and the dinoflagellate $P$. foliaceum (Figure 2A). Conversely, it grew very slowly when fed the small celled Pyramimonas sp. while no growth was observed with the chain forming diatom $T$. weissflogii. Statistically significant differences (Paired $t$-test, $p<0.05$, Supplementary Table 1) were observed between the number of cells in control samples with only Noctiluca and Noctiluca cells fed either P. foliaceum or $P$. tricornutum but this was not the case with cells feed either T. weisflogii or Pyramimonas sp. LL exposed Noctiluca cells (Figure 2B) showed similar food preferences after 14 days but growth was much slower and maximum number of cells was about 5233 cells $\mathrm{L}^{-1}$ in Peridinium fed cultures compared to 25,500 cells $\mathrm{L}^{-1}$ in $\mathrm{HL}$ with the same food. A comparison of all Noctiluca cells grown with prey in HL vs. LL, showed a statistically significant difference (Paired $t$-test, $p<0.05$, Supplementary Table 1) for all four prey cultures indicating the importance of light for endosymbiont photosynthesis and growth of Noctiluca. Growth rates for the preferred food Peridinium increased from 0.1 to $0.3 \mathrm{day}^{-1}$ after 2 days (Figure 3), the latter being the maximum growth rate achieved during the experiment in HL conditions. When Noctiluca was fed Phaeodactylum, the other preferred food, growth rates increased gradually with a maximum growth rate of 0.22 day $^{-1}$ after 14 days. HL exposed Thalassiosira fed Noctiluca did not show any growth for 5 days but a growth rate of 0.17 was observed after 2 days. Although HL Pyramimonas sp. fed Noctiluca, showed an increased growth rate of 0.2 day $^{-1}$ after 7 days, growth rates tapered off and Noctiluca cells did not show increases as observed for the preferred cultures
(Figure 2A). Unfed Noctiluca achieved a maximal growth rate achieved of 0.17 day $^{-1}$ after 12 days but tapered off to almost negligible by end of the experiment. Growth rates were lower in the LL regime than in the HL regime (Paired $t$-test, $p<0.01$ ), except in the case of unfed Noctiluca (after 12 days) wherein a highly inflated growth rate of almost 0.4 day $^{-1}$ was observed. We think this may have been a counting artifact because our duplicate counts after 7 days were highly disparate (67 vs. 1067). Average growth rate of fed cells (all foods) in HL was 0.12 day $^{-1}$ and for LL (all foods) it was $0.05 \mathrm{day}^{-1}$. In the case of HL exposed Peridinium and Phaeodactylum fed cultures, it should be noted that in spite of a decrease in growth rates between 14 and 27 days (Figure 3), the number of Noctilucacells still increased from about 19,600 to 25,500 cells $\mathrm{L}^{-1}$ in the case of Peridinium fed Noctiluca and from 16,270 to 28,600 cells $\mathrm{L}^{-1}$ in the case of Phaeodactylum fed Noctiluca (Figure 2). From day 14 to 21 , in some cases LL adapted cells, also showed a small increase in growth rates (negligible to $\sim 0.10$ day $^{-1}$ ) which led to an increase in the number of cells by the end of the experiment (Figure 2B) and which could possibly be from acclimatization by endosymbionts to light levels which initially had been severely limiting.

\section{Chl a Concentrations of Noctiluca's Endosymbionts}

A slightly different pattern emerged when Noctiluca's intracellular Chl a concentrations per cell were estimated (Figures 4A,B). Intracellular concentrations in cells fed with the two preferred foods increased in the first 7 days but gradually decreased to concentrations approximating those at the start of the experiment. Almost invariant intracellular Chl a concentrations were measured in Pyramimonas sp. fed cells over the experimental period.

After 14 days, when intracellular Chl a concentrations of HL exposed cells began to decrease subsequent to a peak of 0.6-2.0 $\mu \mathrm{g} \mathrm{cell}^{-1}$, a reverse situation was observed in LL light adapted cells where intracellular Chl $a$ increased almost twofold especially in Noctiluca fed the two preferred foods and fourfold 
with the other two foods as well as in the unfed Noctiluca (Figures 4A,B). One reason for this is that higher growth, cell division and an increase in cell numbers in the HL grown cells compared to those in LL, resulted in smaller cells in HL exposed cultures which contained less endosymbionts and consequently lower intracellular Chl $a$. The other, probably relates to pigment packaging invariably observed in phytoplankton cells growing under low light. When exposed for prolonged periods to low light, phytoplankton cells usually increase their pigment concentration and change the organization of pigments within their photosynthetic units to aid in harvesting light (Falkowski and Owens, 1980). However, pigment molecules, when tightly packed instead of being uniformly distributed within the cell, lessen the overall effectiveness in collecting photons from the prevailing irradiance field, lowering their efficiency of light absorption and consequently the amount of carbon fixation (Morel and Bricaud, 1981; Sosik and Mitchell, 1994). We believe that the increase in Chl $a$ in Noctiluca cells growing under LL conditions is akin to pigment packaging in phytoplankton cells.

\section{ETR vs. E Curves and Model Derived Photosynthetic Parameters}

Figures 5A-F compares ETR vs. E curves in HL (Figures 5A-C) and LL (Figures 5D-F) regimes for Noctiluca cells grown with the two preferred foods $P$. foliaceum and $P$. tricornutum and unfed Noctiluca. All curves are an average of four replicate measurements. Both the light limited (initial) and light saturated parts of the curves from HL and LL exposed cells responded markedly to changes in irradiances. Maximum ETR $\left(\mathrm{ETR}_{\max }\right)$ or the maximum photosynthetic capacity was clearly higher in HL exposed cells than in LL cells. Average $\mathrm{ETR}_{\max }$ was 236 electrons $\mathrm{s}^{-1} \mathrm{RC}^{-1}$ (electrons $\mathrm{s}^{-1}$ Reaction Center ${ }^{-1}$ ) in HL exposed cells as opposed to 154 electrons $\mathrm{s}^{-1} \mathrm{RC}^{-1}$ in $\mathrm{LL}$ exposed cells. The differences in ETR $_{\max }$ between HL and LL exposed cells were statistically significant (Paired $t$-test, $p<0.001$; Supplementary Table S1). The rate of increase of light-limited ETR $(\alpha)$, which is the slope of the initial part of the curve and quantifies the efficiency of light capture averaged 2.0 electrons $\mathrm{m}^{2}$ $\mathrm{RC}^{-1} \mu$ mole quanta ${ }^{-1}$ compared to 1.5 electrons $\mathrm{m}^{2} \mathrm{RC}^{-1}$ $\mu$ mole quanta ${ }^{-1}$ for LL exposed cells. The differences in $\alpha$, derived from curves of HL and LL exposed cells was also statistically significant (Paired $t$-test, $p<0.005$; Supplementary Table S1). The saturating irradiance for ETR $\left(E_{k}\right)$ which represents the optimal irradiance for photosynthesis was lower (average $380 \mu$ mole quanta ${ }^{-1} \mathrm{~s}^{-1}$ ) in LL exposed cells compared to that of cells exposed to HL (124 $390 \mu$ mole quanta $^{-1} \mathrm{~s}^{-1}$ ) although this difference was not statistically significant.

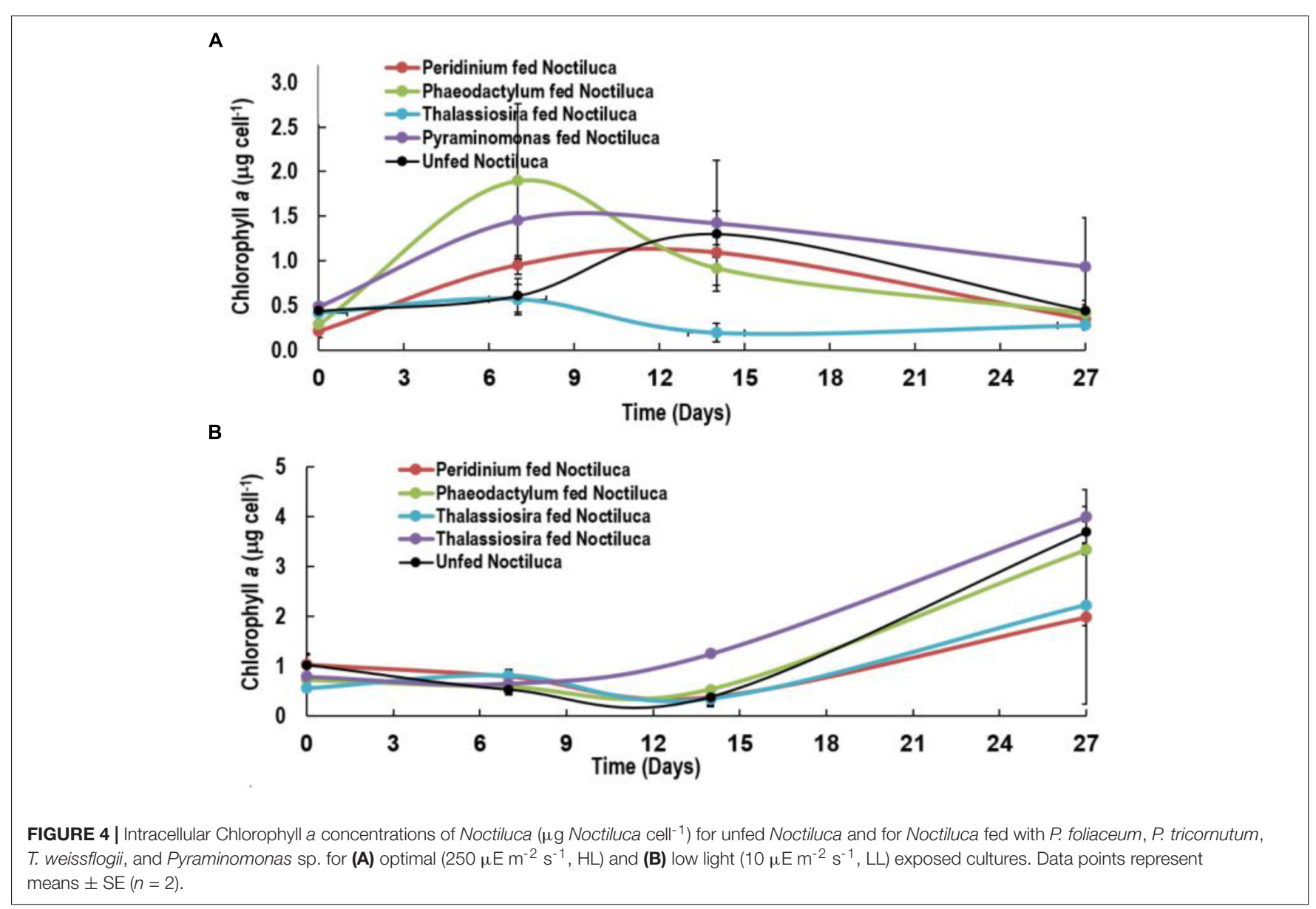



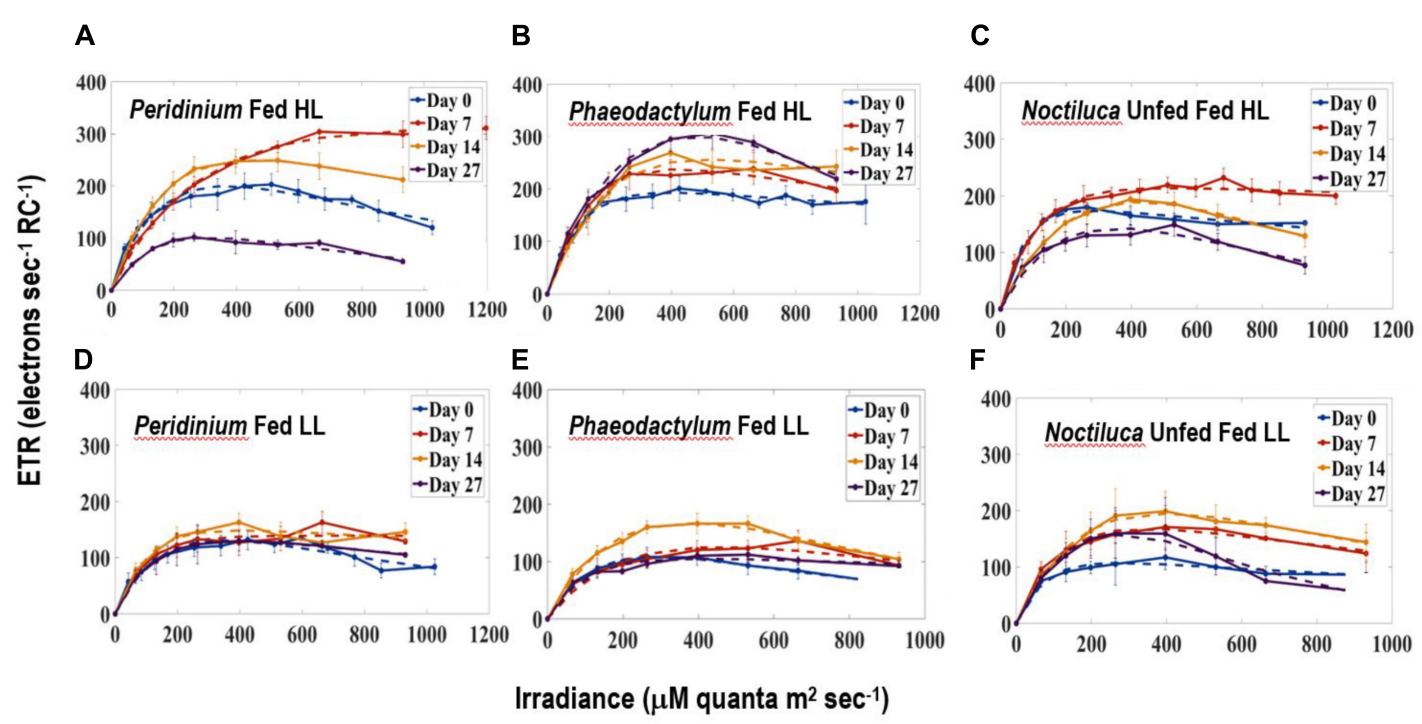

FIGURE 5 | Electron Transport Rates-Irradiance (ETR-E) curves for (A) P. foliaceum fed Noctiluca cells in HL (B) P. tricornutum fed Noctiluca cells in HL (C) Unfed Noctiluca cells in $\mathrm{HL}\left(250 \mu \mathrm{E} \mathrm{m}^{-2} \mathrm{~s}^{-1}\right)$ fitted to the function of Platt et al. (1980), as described in Section "Materials and Methods." ETR is expressed as electrons $\mathrm{s}^{-1}$ Reaction Center $^{-1}$. (D-F) are for the same but exposed to LL $\left(10 \mu \mathrm{E} \mathrm{m}^{-2} \mathrm{~s}^{-1}\right)$. Data points represent means $\pm \mathrm{SE}(n=4)$.

Comparison of the parameters of the ETR vs. E curves obtained from fed and unfed cultures in HL exposed cells, provides us with information on whether food enhances the photosynthetic activity of the endosymbionts.

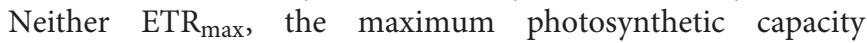
nor $\alpha$, the maximum rate of increase of light-limited photosynthesis, from both $P$. foliaceum and $P$. tricornutum fed cultures of Noctiluca in HL, were statistically different from those derived from unfed Noctiluca in the same light regime. This indicates that the endosymbionts in both fed and unfed cultures were not under any nutrient stress.

\section{Intracellular Concentrations of $\mathbf{N H}_{4}{ }^{+}$}

Although there are several reports on the accumulation of $\mathrm{NH}_{4}{ }^{+}$ in red Noctiluca (Okaichi and Nishio, 1976; Zhang et al., 2017) no such exist for green Noctiluca. This first report on the per cell intracellular concentrations of $\mathrm{NH}_{4}{ }^{+}$in green Noctiluca in $\mathrm{HL}$ exposed cells (Figure 6A) show that highest $\mathrm{NH}_{4}{ }^{+}$ accumulation occurred on day 14 but decreased to undetectable concentrations 4 days later. This indicates rapid uptake of $\mathrm{NH}_{4}{ }^{+}$by the green endosymbionts. $\mathrm{NH}_{4}{ }^{+}$concentrations below detection levels were observed in cells fed the preferred food, $P$. foliaceum while the second lowest $\left(0.0025 \mu \mathrm{M} \mathrm{NH}_{4}{ }^{+}\right.$cell $\left.^{-1}\right)$ concentration was found in $P$. tricornutum fed cells. The highest accumulation $\left(0.01 \mu \mathrm{M} \mathrm{NH}{ }_{4}{ }^{+}\right.$cell $\left.^{-1}\right)$ was observed in cells fed the least preferred food, Pyramimonas sp. This can tentatively suggest higher uptake of $\mathrm{NH}_{4}{ }^{+}$by the green endosymbionts in cells that were fed the favored foods. Highest $\mathrm{NH}_{4}{ }^{+}$accumulation of $0.006 \mathrm{NH}_{4}{ }^{+} \mu \mathrm{M}$ cell $^{-1}$ was measured in unfed samples. In contrast, $\mathrm{LL}$ exposed cells intracellular $\mathrm{NH}_{4}{ }^{+}$ concentrations were almost an order higher than those in $\mathrm{HL}$ exposed cells (Figure 6B). This is an indication that nutrient uptake by endosymbionts was lower when photosynthesis was light limited.

\section{DISCUSSION}

The strain of green Noctiluca from the Arabian Sea showed a distinct preference for P. foliaceum and P. tricornutum. Although it also grew without food especially in HL exposed cells, growth rates were almost half of that in the fed cultures and cell counts were five-fold higher in the latter after 14 days of feeding. The only other study on feeding and food preference in green Noctiluca (Hansen et al., 2004) isolated from the Manila Bay, Philippines showed a preference for two dinoflagellates Pyrodinium bahamense and Akashiwo sanguinea. The difference between these two studies is that irrespective of food type, food concentration, and irradiance, the Noctiluca culture in the study of Hansen et al. (2004) lost its endosymbionts after about 3 weeks and became colorless and died. This was not the case with the Arabian Sea Noctiluca culture which continued to grow albeit slowly even after the end of the experiment. Both, the current study and our previous one conducted in the Arabian Sea (Gomes et al., 2014) where natural populations of Noctiluca were fed a mixed phytoplankton bloom predominated by diatoms showed similar results to those obtained by Hansen et al. (2004) in that growth rates were higher for fed cultures than for unfed Noctiluca.

Our recalculated growth rates are concurrent with those of Hansen et al. (2004), which were 0.14 day $^{-1}$ for HL and 0.058 day $^{-1}$ for LL at comparable irradiances.

Our study clears shows that irrespective of the quality of food provided, adequate light is required for green Noctiluca to grow which reiterates findings from the earlier two studies 

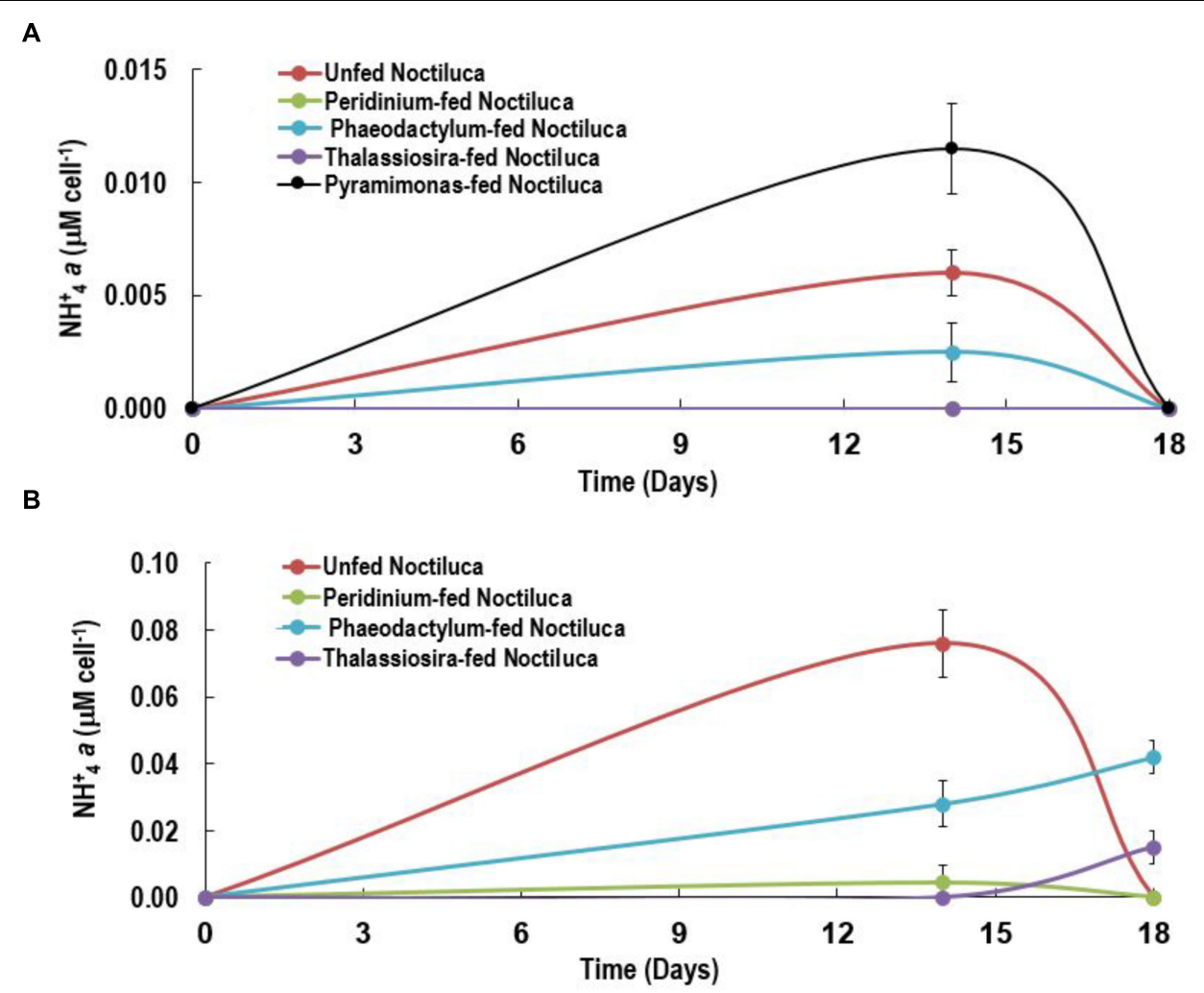

FIGURE 6 | Intracellular $\mathrm{NH}^{+}{ }_{4}$ concentrations of Noctiluca ( $\mu \mathrm{g}$ Noctiluca cell ${ }^{-1}$ ) for unfed Noctiluca and for Noctiluca fed with P. foliaceum, P. tricornutum, T. weissflogii, and Pyramimonas sp. for $(\mathbf{A})$ optimal $(\mathrm{HL})$ and $\mathbf{( B )}$ low light $(\mathrm{LL})$ exposed cultures. Data points represent means $\pm \mathrm{SE}(n=2)$.

(Hansen et al., 2004; Gomes et al., 2014). This is also clearly observed is in the ETR vs. E curves where higher ETR $\max$ or maximum photosynthetic capacity was observed in HL exposed cells. Beyond this maxima, the rate of photosynthesis is limited by the activity of the electron transport chain or Calvin cycle (Serôdio et al., 2005).

The non-intrusive technique of ETR vs. E curves which we utilized yielded an interesting result in that the type of food provided did not change the photosynthetic response of the endosymbionts as there was no statistically significant relationship in the ETR vs. E parameters of fed (including the two preferred foods) and unfed Noctiluca cells. In addition to responding to variations in irradiance, both $\mathrm{P}$-E curves and variable fluorescence are sensitive to changes in nutrient and trace metal concentrations (Falkowski and Kolber, 1995; Behrenfeld and Kolber, 1999; Bouman et al., 2005). The similarity in photosynthetic parameters between fed and unfed Noctiluca indicates that endosymbionts did not experience nutrient variations especially nutrient limitation in either of the two treatments. Using two types of cultures, one that required feeding to survive and the other which like our culture survived for extended periods without food, Saito et al. (2006) performed P-E curves where photosynthesis was measured using oxygen concentrations. They too observed no significant differences in gross photosynthetic rate between the feeding and non-feeding rate but net photosynthesis was higher in the non-feeding strain because feeding strains showed higher rates of respiration. Our ETRs (normalized to PSII reaction center content and expressed as electrons $\mathrm{s}^{-1} \mathrm{RC}^{-1}$ ), generated from active fluorescent measurements are being recognized as superior, instantaneous and non-intrusive alternatives to the traditional methods of oxygen evolution or assimilation of $\mathrm{CO}_{2}$ especially in controlled experiments such as those undertaken here where the photophysiology of phytoplankton subjected to different treatments is being examined (Silsbe et al., 2015; Schuback et al., 2016).

Our current experiments suggest that $\mathrm{NH}_{4}{ }^{+}$accumulation prevents endosymbiont nutrient limitation which we evidenced from the invariant parameters of the ETR-E curves for both fed and non-fed cells. This is indicated by higher accumulation of $\mathrm{NH}_{4}{ }^{+}$in $\mathrm{LL}$ exposed vs. HL exposed cells suggesting higher uptake rates of $\mathrm{NH}_{4}{ }^{+}$when light levels were more conducive for $\mathrm{NH}_{4}{ }^{+}$uptake and phytoplankton growth (MacIsaac and Dugdale, 1972). Although it is likely that the endosymbionts benefited from the accumulation of $\mathrm{NH}_{4}{ }^{+}$in Noctiluca cells we have to approach this conclusion with caution as we presently do not have the $\mathrm{NH}_{4}{ }^{+}$concentrations in the treatment bottles which would have provided us with information as to whether ammonia could have been excreted into the media. Excretion of $\mathrm{NH}_{4}{ }^{+}$by blooms of red Noctiluca has been documented (Okaichi and Nishio, 1976; Montani et al., 1998; Ara et al., 2013) which in times of bloom can enhance growth of other phytoplankton (Ara et al., 2013). We have however 
not observed enhanced nutrients from the large scale blooms of green Noctiluca that we have reported previously in the Arabian Sea (Gomes et al., 2008, 2009, 2014). The fact that our culture of Noctiluca can survive for several months without food nor replenishment of nutrients in the media suggests a tight recycling of nutrients which allow endosymbionts to grow as well as support the growth of the host Noctiluca (Furuya et al., 2006a). Using an algal culture with differing $\mathrm{N}$ and $\mathrm{P}$ elemental composition Zhang et al. (2017) showed that the heterotrophic red Noctiluca strictly regulates its stoichiometry which allows it to tide over when resources are scarce. Total cellular elemental ratios of this red Noctiluca strain were nearly homeostatic, although its intracellular pools of $\mathrm{NH}_{4}{ }^{+}$and $\mathrm{PO}_{4}{ }^{+}$were weakly regulated. Additionally, this strain of red Noctiluca, was found to regulate its internal $\mathrm{N}$ more strongly and efficiently than its $\mathrm{P}$ content making it more vulnerable to $\mathrm{P}$ limitation. If this is also the case with green Noctiluca, it can explain its predominance in the Arabian Sea (Gomes et al., 2008, 2009) which is severely $\mathrm{N}$ but not $\mathrm{P}$ limited (Morrison et al., 1999). Future studies such as that of Zhang et al. (2017) with green Noctiluca will better enable us to understand what has triggered the recent and pervasive annual blooms of Noctiluca in the Arabian Sea which portend to cause severe repercussion for the marine resources of great economic and cultural significance to the more than 86 million people living along the coast. In the Arabian Sea, Noctiluca does not appear to be a preferred food source for common mesozooplankton and instead appears to be consumed by jellyfish and salps potentially casing disruptions to the traditional diatom-sustained food chain (Gomes et al., 2014).

More studies such as these are required to better understand the interplay between autotrophy and heterotrophy in the green Noctiluca so that mixotrophy can be included in conceptual and mathematical models. The current exclusion of mixotrophy misrepresents the functioning of the biological pump with important implications for our understanding of the influence of climate change on aquatic ecosystems (Mitra et al., 2014).

\section{CONCLUSION}

The recently isolated mixotrophic strain of green Noctiluca which harbors large populations of the Chlorophyte $P$. noctilucae yielded some interesting results on its mode of nutrition that could complicate the description and modeling of food web structures in pelagic ecosystems. The green Noctiluca showed a definite preference for certain algal foods preferring the dinoflagellate $P$. foliaceum and the pennate diatom $P$. tricornutum to another diatom $T$. weissflogii and the chlorophyte Pyramimonas sp. However, regardless of the food provided, light was necessary for Noctiluca to grow and growth was severely diminished at low irradiances of around $10 \mu \mathrm{E} \mathrm{m} \mathrm{m}^{-2} \mathrm{~s}^{-1}$. This was confirmed by the instantaneous and non-intrusive measurements of variable fluorescence derived ETRs. However, when exposed to adequate light levels, however, ETR did not show any change in cells that were fed the preferred foods and those that were not indicating that the green endosymbionts were not nutritionally starved. The tight recycling of nutrients internally is indicated by the fact that our Noctiluca culture is able to sustain itself for several months without extraneous food or nutrients. Our first of their kind albeit preliminary measurements on the intracellular concentration of ammonia suggests that in the presence of adequate light, ammonia which accumulated early in the experiment decreased to undetectable levels soon after indicating uptake by the green endosymbionts.

\section{AUTHOR CONTRIBUTIONS}

HG and JG conceived and planned the experiments. $H G$ processed the data and wrote the paper. KM planned and conducted the experiments. AM and ST conducted the experiments. KA-H provided insights on Noctiluca's physiology from field studies for growing it in culture. XJ processed the data.

\section{FUNDING}

This work was supported in part by grants from Gordon Betty Moore Foundation, United States, the Sultan Qaboos Culture Center, United States and from NASA (NNX17AG66GECO4CAST) to JG and HG. AM acknowledges support from the NSF program "Research Experience for Undergraduates." ST acknowledges the support of Peddie School, Hightstown, NJ, United States where she was a High School student when this work was undertaken. XJ was supported by the Chinese Scholarship Council.

\section{ACKNOWLEDGMENTS}

We thank Dr. Daniel Kaufman, Chesapeake Research Consortium, MD for providing the curve fitting MATLAB code. We are grateful to our colleague, Prof. O. Roger Anderson, Columbia University for his insights and support for this and related work.

\section{SUPPLEMENTARY MATERIAL}

The Supplementary Material for this article can be found online at: $\quad$ https://www.frontiersin.org/articles/10.3389/fmars.2018. 00374/full\#supplementary-material

FIGURE S1 | Schematic of experimental set-up of Noctiluca cells fed with four types of algal food as well as unfed cells all exposed to optimal light $\left(250 \mu \mathrm{E} \mathrm{m}^{-2}\right.$ $\left.\mathrm{s}^{-1}, \mathrm{HL}\right)$. A similar and parallel experiment was set up under low light $\left(10 \mu \mathrm{E} \mathrm{m}^{-2}\right.$ $\left.\mathrm{S}^{-1}, \mathrm{LL}\right)$.

TABLE S1 | Statistically significant levels for comparison of HL vs. $L L(n=25)$, fed and unfed Noctiluca cell counts $(n=7)$ and for the parameters of the ETR-E curves $(n=4)$. P values were obtained using a two-sample $t$-test. All statistically significant levels $(p<0.05)$ for $p$-values are denoted by *. 


\section{REFERENCES}

Al-Azri, A., Piontkovski, S., Al-Hashmi, K., Al-Gheilani, H., Al-Habsi, H., AlKhusaibi, S., et al. (2012). The occurrence of algal blooms in Omani coastal waters. Aquat. Ecosyst. Health Manage. 15, 56-63. doi: 10.1080/14634988.2012. 672151

Al-Hashmi, K. A., Smith, S. L., Claereboudt, M., Piontkovski, S. A., and Al-Azri, A. (2015). Dynamics of potentially harmful phytoplankton in a semi-enclosed bay in the Sea of Oman. Bull. Mar. Sci. 91, 141-166. doi: 10.5343/bms.2014.1041

Ara, K., Nakamura, S., Takahashi, R., Shiomoto, A., and Hiromi, J. (2013). Seasonal variability of the red tide-forming heterotrophic dinoflagellate Noctiluca scintillans in the neritic area of Sagami Bay, Japan: its role in the nutrientenvironment and aquatic ecosystem. Plankton Benthos Res. 8, 9-30. doi: 10. 3800/pbr.8.9

Banse, K., and McClain, C. R. (1986). Winter blooms of phytoplankton in the Arabian Sea as observed by the Coastal Zone Color Scanner. Mar. Ecol. Prog. Ser. 34, 201-211. doi: 10.3354/meps034201

Behrenfeld, M. J., and Kolber, Z. S. (1999). Widespread iron limitation of phytoplankton in the South Pacific Ocean. Science 283, 840-843. doi: 10.1126/ science.283.5403.840

Bibby, T. S., Gorbunov, M. Y., Wyman, K. W., and Falkowski, P. G. (2008). Photosynthetic community responses to upwelling in mesoscale eddies in the subtropical North Atlantic and Pacific Oceans. Deep Sea Res. Part II 55, 1310-1320. doi: 10.1016/j.dsr2.2008.01.014

Bouman, H., Platt, T., Sathyendranath, S., and Stuart, V. (2005). Dependence of light-saturated photosynthesis on temperature and community structure. Deep Sea Res. Part I 52, 1284-1299. doi: 10.1016/j.dsr.2005.01.008

Breitburg, D., Levin, L. A., Oschlies, A., Grégoire, M., Chavez, F. P., Conley, D. J., et al. (2018). Declining oxygen in the global ocean and coastal waters. Science 359:eaam7240. doi: 10.1126/science.aam7240

Caron, D. A. (2016). Mixotrophy stirs up our understanding of marine food webs. Proc. Natl. Acad. Sci. U.S.A. 113, 2806-2808. doi: 10.1073/pnas.1600718113

Caron, D. A. (2017). Acknowledging and incorporating mixed nutrition into aquatic protistan ecology, finally. Environ. Microbiol. Rep. 9, 41-43. doi: 10. 1111/1758-2229.12514

Elbrachter, M., and Qi, Y.-Z. (1998). “Aspects of Noctiluca (Dinophyceae) population dynamics," in Physiological Ecology of Harmful Algal Blooms, eds D. M. Andersen, A. Cembella and G. M. Hallegraeff. (Berlin: NATO ASI Series), 315-335.

Falkowski, P., and Kolber, Z. (1995). Variations in chlorophyll fluorescence yields in phytoplankton in the world oceans. Funct. Plant Biol. 22, 341-355.

Falkowski, P. G., Owens, T. H. G., Ley, A. C., and Mauzerall, D. C. (1981). Effects of growth irradiance levels on the ratio of reaction centers in two species of marine phytoplankton. Plant Physiol. 68, 969-973. doi: 10.1104/pp.68.4.969

Falkowski, P. G., and Owens, T. G. (1980). Light-shade adaptation. two strategies. Mar. Phytoplankton 66, 592-595.

Furuya, K., Saito, H., Rujinard, S., Vijayan, A. K., Omura, T., Furio, E. E., et al. (2006a). Persistent whole-bay red tide of Noctiluca scintillans in Manila Bay, Philippines. Coast. Mar. Sci. 30, 74-79.

Furuya, K., Saito, H., Sriwoon, R., Omura, T., Furio, E., Borja, V., et al. (2006b). Vegetative growth of Noctiluca scintillans containing the endosymbiont Pedinomonas noctilucae. Afr. J. Mar. Sci. 28, 305-308. doi: 10.2989/ 18142320609504167

Goes, J. I., and Gomes, H. D. R. (2016). "An ecosystem in transition: the emergence of mixotrophy in the Arabian Sea", in Aquatic Microbial Ecology and Biogeochemistry: A Dual Perspective, eds P. Glibert and T. Kana (Newyork, NY: Springer International Publishing), 245.

Goes, J. I., Prasad, T. G., Gomes, H. D. R., and Fasullo, J. T. (2005). Warming of the Eurasian landmass is making the Arabian Sea more productive. Science 308, 545-547. doi: 10.1126/science.1106610

Goes, J. I., Gomes, H. D. R., Al-Hashimi, K., and Buranapratheprat, A. (2018). "Ecological drivers of green Noctiluca blooms in two monsoonaldriven ecosystems," in Global Ecology and Oceanography of Harmful Algal Blooms, eds P. M. Glibert, E. Berdalet, M. A. Burford, G. C. Pitcher and M. Zhou (Cham: Springer International Publishing), 327-336. doi: 10.1007/978-3-319-70069-4_17

Gomes, H., Goes, J. I., Matondkar, S. G. P., Parab, S. G., Al-Azri, A., and Thoppil, P. G. (2009). "Unusual blooms of the green Noctiluca miliaris (Dinophyceae) in the Arabian Sea during the winter monsoon," in Indian Ocean: Biogeochemical Processes and Ecological Variability, eds J. D. Wiggert, R. R. Hood, S. W. A. Naqvi, S. L. Smith and K. H. Brink (Washington, DC: American Geophysical Union), 347-363. doi: 10.1029/2008GM000831

Gomes, H. D. R., Goes, J. I., Matondkar, S. G. P., Buskey, E. J., Basu, S., Parab, S., et al. (2014). Massive outbreaks of Noctiluca scintillans blooms in the Arabian Sea due to spread of hypoxia. Nat. Commun. 5:4862. doi: 10.1038/ncomms5862

Gomes, H. D. R., Goes, J. I., Matondkar, S. G. P., Parab, S. G., Al-Azri, A. R. N., and Thoppil, P. G. (2008). Blooms of Noctiluca miliaris in the Arabian Sea - An in situ and satellite study. Deep Sea Res. Part I 55, 751-765. doi: 10.1016/j.dsr. 2008.03.003

Gorbunov, M. Y., and Falkowski, P. G. (2004). "Fluorescence Induction and Relaxation (FIRe) technique and instrumentation for monitoring photosynthetic process and primary production in aquatic ecosystems," in Photosynthesis: Fundamental Aspects to Global Perspectives, eds A. V. D. Est and D. Bruce (Lawrence, KS: Allen Press), 1029-1031.

Hansen, P. J., Miranda, L., and Azanza, R. (2004). Green Noctiluca scintillans: a dinoflagellate with its own greenhouse. Mar. Ecol. Prog. Ser. 275, 79-87. doi: 10.3354/meps 275079

Harrison, P. J., Furuya, K., Glibert, P. M., Xu, J., Liu, H. B., Yin, K., et al. (2011). Geographical distribution of red and green Noctiluca scintillans. Chin. J. Oceanol. Limnol. 29, 807-831. doi: 10.1007/s00343-011-0510-z

Henley, W. J. (1993). Measurement and interpretation of photosynthetic lightresponse curves in algae in the context of photoinhibition and diel changes. J. Phycol. 29, 729-739. doi: 10.1111/j.0022-3646.1993.00729.x

Holmes, R. M., Aminot, A., Kérouel, R., Hooker, B. A., and Peterson, B. J. (1999). A simple and precise method for measuring ammonium in marine and freshwater ecosystems. Can. J. Fish. Aquat. Sci. 56, 1801-1808. doi: 10.1139/f99-128

Holm-Hansen, O., and Riemann, B. (1978). Chlorophyll a determination: improvements in methodology. Oikos 30, 438-447. doi: 10.2307/3543338

Houliez, E., Lefebvre, S., Lizon, F., and Schmitt, F. G. (2017). Rapid light curves (RLC) or non-sequential steady-state light curves (N-SSLC): which fluorescence-based light response curve methodology robustly characterizes phytoplankton photosynthetic activity and acclimation status? Mar. Biol. 164:175. doi: 10.1007/s00227-017-3208-8

Kolber, Z. S., Prášil, O., and Falkowski, P. G. (1998). Measurements of variable chlorophyll fluorescence using fast repetition rate techniques: defining methodology and experimental protocols. Biochim. Biophys. Acta 1367, 88-106. doi: 10.1016/S0005-2728(98)00135-2

Lachkar, Z., Lévy, M., and Smith, S. (2017). Intensification and deepening of the Arabian Sea oxygen minimum zone in response to increase in Indian monsoon wind intensity. Biogeosciences 15, 159-186. doi: 10.5194/bg-15-159-2018

Leles, S. G., Mitra, A., Flynn, K. J., Stoecker, D. K., Hansen, P. J., Calbet, A., et al. (2017). Oceanic protists with different forms of acquired phototrophy display contrasting biogeographies and abundance. Proc. R. Soc. B Biol. Sci. 284:20170664 doi: 10.1098/rspb.2017.0664

MacIsaac, J. J., and Dugdale, R. C. (1972). Interactions of light and inorganic nitrogen in controlling nitrogen uptake in the sea. Deep Sea Res. Oceanogr. Abstr. 19, 209-232. doi: 10.1016/0011-7471(72)90032-0

Mitra, A., Flynn, K. J., Burkholder, J. M., Berge, T., Calbet, A., Raven, J. A., et al. (2014). The role of mixotrophic protists in the biological carbon pump. Biogeosciences 11, 995-1005. doi: 10.5194/bg-11-995-2014

Mitra, A., Flynn, K. J., Tillmann, U., Raven, J. A., Caron, D., Stoecker, D. K., et al. (2016). Defining planktonic protist functional groups on mechanisms for energy and nutrient acquisition: incorporation of diverse mixotrophic strategies. Protist 167, 106-120. doi: 10.1016/j.protis.2016.01.003

Montani, S., Pithakpol, S., and Tada, K. (1998). Nutrient regeneration in coastal seas by Noctiluca scintillans, a red tide-causing dinoflagellate. J. Mar. Biotechnol. 6, 224-228.

Morel, A., and Bricaud, A. (1981). Theoretical results concerning light absorption in a discrete medium, and application to specific absorption of phytoplankton. Deep Sea Res. Part A 28, 1375-1393. doi: 10.1016/0198-0149(81)90039-X

Morrison, J. M., Codispoti, L. A., Smith, S. L., Wishner, K., Flagg, C., Gardner, W. D., et al. (1999). The oxygen minimum zone in the Arabian Sea during 1995. Deep Sea Res. II 46, 1903-1931. doi: 10.1016/S0967-0645(99)00048-X

Okaichi, T., and Nishio, S. (1976). Identification of ammonia as the toxic principle of red tide Noctiluca miliaris. Bull. Plankton Soc. Japan 23, 75-80. 
Park, J., Park, T., Yang Eun, J., Kim, D., Gorbunov Maxim, Y., Kim, H. C., et al. (2013). Early summer iron limitation of phytoplankton photosynthesis in the Scotia Sea as inferred from fast repetition rate fluorometry. J. Geophys. Res. Oceans 118, 3795-3806. doi: 10.1002/jgrc.20281

Platt, T., Gallegos, C. L., and Harrison, W. G. (1980). Photoinhibition of photosynthesis in natural assemblages of marine phytoplankton. J. Mar. Res. 38, 103-111.

Platt, T., and Jassby, A. D. (1976). The relationship between photosynthesis and light for natural assemblages of coastal marine phytoplankton. J. Phycol. 12, 421-430. doi: 10.1111/j.1529-8817.1976.tb02866.x

Platt, T., and Sathyendranath, S. (1988). Oceanic primary production: estimation by remote sensing at local and regional scales. Science 241, 1613-1620. doi: $10.1126 /$ science.241.4873.1613

Poulton, N. J. (2016). "FlowCam: quantification and classification of phytoplankton by imaging flow cytometry," in Imaging Flow Cytometry: Methods and Protocols, eds N. S. Barteneva and I. A. Vorobjev (New York, NY: Springer), 237-247.

Saito, H., Furuya, K., and Lirdwitayaprasir, T. (2006). Photoautotrophic growth of Noctiluca scintillans with the endosymbiont Pedinomonas noctilucae. Plankton Benthos Res. 1, 97-101. doi: 10.3800/pbr.1.97

Schuback, N., Flecken, M., Maldonado, M. T., and Tortell, P. D. (2016). Diurnal variation in the coupling of photosynthetic electron transport and carbon fixation in iron-limited phytoplankton in the NE subarctic Pacific. Biogeosciences 13, 1019-1035. doi: 10.5194/bg-13-1019-2016

Serôdio, J., Vieira, S., Cruz, S., and Barroso, F. (2005). Short-term variability in the photosynthetic activity of microphytobenthos as detected by measuring rapid light curves using variable fluorescence. Mar. Biol. 146, 903-914. doi: 10.1007/s00227-004-1504-6

Silsbe, G. M., Oxborough, K., Suggett, D. J., Forster, R. M., Ihnken, S., Komárek, O., et al. (2015). Toward autonomous measurements of photosynthetic electron transport rates: an evaluation of active fluorescence-based measurements of photochemistry. Limnol. Oceanogr. Methods 13:e10014. doi: 10.1002/lom3. 10014

Sosik, H. M., and Mitchell, B. G. (1994). Effects of temperature on growth, light absorption, and quantum yield in Dunaliella tertiolecta (Chlorophycea). J. Phycol. 30, 833-840. doi: 10.1111/j.0022-3646. 1994.00833.x

Sriwoon, R., Pholpunthin, P., Lirdwitayaprasit, T., Kishino, M., and Furuya, K. (2008). Population dynamics of green Noctiluca scintillans (Dinophyceae) associated with the monsoon cycle in the upper Gulf of Thailand. J. Phycol. 44, 605-615. doi: 10.1111/j.1529-8817.2008.00516.x

Stoecker, D. K., Hansen, P. J., Caron, D. A., and Mitra, A. (2017). Mixotrophy in the marine plankton. Annu. Rev. Mar. Sci. 9, 311-335. doi: 10.1146/annurevmarine-010816-060617

Stoecker, D. K., Johnson, M. D., Devargas, C., and Not, F. (2009). Acquired phototrophy in aquatic protists. Aquat. Microb. Ecol. 57, 279-310. doi: 10.3354/ ame01340

Suggett, D. J., Moore, C. M., Hickman, A. E., and Geider, R. J. (2009). Interpretation of fast repetition rate (FRR) fluorescence: signatures of phytoplankton community structure versus physiological state. Mar. Ecol. Prog. Ser. 376, 1-19. doi: $10.3354 /$ meps07830

Sweeney, B. M. (1971). Laboratory studies of a Green Noctiluca from New Guinea. J. Phycol. 7, 53-58. doi: 10.1111/j.1529-8817.1971.tb01478.x

Sweeney, B. M. (1976). Pedinomonas noctilucae (Prasinophyceae) the flagellate symbiotic in Noctiluca (Dinophyceae) in Southeast Asia. J. Phycol. 12, 460-464.

Wang, L., Lin, X., Goes, J. I., and Lin, S. (2016). Phylogenetic analyses of three genes of Pedinomonas noctilucae, the green Endosymbiont of the marine Dinoflagellate Noctiluca scintillans, reveal its affiliation to the order Marsupiomonadales (Chlorophyta, Pedinophyceae) under the reinstated name Protoeuglena noctilucae. Protist 167, 205-216. doi: 10.1016/j.protis.2016.02.005

Zhang, S., Liu, H., Glibert, P. M., Guo, C., and Ke, Y. (2017). Effects of prey of different nutrient quality on elemental nutrient budgets in Noctiluca scintillans. Sci. Rep. 7:7622. doi: 10.1038/s41598-017-05991-w

Zhang, S., Liu, H., Guo, C., and Harrison, P. J. (2016). Differential feeding and growth of Noctiluca scintillans on monospecific and mixed diets. Mar. Ecol. Prog. Ser. 549, 27-40. doi: 10.3354/meps 11702

Conflict of Interest Statement: The authors declare that the research was conducted in the absence of any commercial or financial relationships that could be construed as a potential conflict of interest.

Copyright (c) 2018 Gomes, McKee, Mile, Thandapu, Al-Hashmi, Jiang and Goes. This is an open-access article distributed under the terms of the Creative Commons Attribution License (CC BY). The use, distribution or reproduction in other forums is permitted, provided the original author(s) and the copyright owner(s) are credited and that the original publication in this journal is cited, in accordance with accepted academic practice. No use, distribution or reproduction is permitted which does not comply with these terms. 